\title{
The Application of Cultural Equivalence and Acceptability Principles in the Translation of East of the West
}

\author{
Yang Jing \\ School of Foreign Languages and Culture, Nanjing Normal University \\ 122 Ninghai Road, Nanjing 210097, China \\ E-mail: yangjing@njnu.edu.cn
}

Received: 10-10- 2014

Published: 01-05- 2015
Accepted: 24-12- 2014

doi:10.7575/aiac.ijalel.v.4n.3p.154
Advance Access Published: January 2015

URL: http://dx.doi.org/10.7575/aiac.ijalel.v.4n.3p.154

\begin{abstract}
Translation is regarded as a kind of transplantation of culture and the role of a translator plays is no other than a bridge between two different cultures. It becomes an important mission for the translator to deal with exotic cultural elements appropriately in order to achieve a better communication between cultures. In this paper, the author selected and analyzed examples from the practical translation of East of the West by adopting the cultural equivalence and acceptability principles, and arrived at the conclusion that only through the expression equilibration and the dynamic integration between these two principles can the translator realize the optimum efficiency of cultural exchange.
\end{abstract}

Keywords: cultural equivalence principle, acceptability principle, East of the West

\section{Introduction}

East of the West: A Country in Stories is a short story collection written by Miroslav Penkov, an immigrant American writer from Bulgaria. It has won international acclaim such as the BBC Short Stories Award and O Henry Prize in 2013 and so far has been translated into many foreign languages and published in at least 11 countries including Germany, France and Spanish. There are stories of Bulgarians tied to their land but dreaming of the West, and the stories dealing with the lives of Bulgarians in Europe and America at present.

Miroslav Penkov was born in a small city in Bulgaria in 1982, and moved to the capital city Sofia with his whole family when he was four years old. He graduated from the local school in the 1990s, when with no hope to realize his dream in his own country, Penkov decided to try his fortune in America, a place worshiped by many young people in East Europe. He got a scholarship and arrived in the USA to attend the University of Arkansas in 2001. At the beginning, he majored in science; but he never dropped his dream of being a real novelist. His writing career began from an MFA (Master of Fine Arts) in creative writing to a job teaching creative writing at the University of North Texas and a position as the fiction editor of the American Literary Review. Eleven years after arriving in America, he published one of the most exciting debut collections in 2011, telling past stories and ancient legends which are strange and rare to modern readers. When Penkov himself translated it into his mother language, it became a best-seller in Bulgaria in 2012.

In East of the West, as some critic pointed out, there mixed with two kind of complex and unspeakable emotions: the beauty of the absurdity of Eastern Europe as well as a certain ambivalence of self-imposed exile of protagonist. He uses English, his non-native language, to tell us about such a bittersweet story with his own sense of history, sense of humor, along with the ability to create eternal artistic images. This collection well depicts the East, the West, and their "middle ground"(杨靖，2013).

After reading through the whole story, the author notices that Penkov employs many special images, which are of great novelty and unique. For instance, when describing a boy that feels strong homesickness in the American university campus, Penkov writes like this: "My loneliness rose up in me like steam over a barren field"(p.66) ${ }^{\mathrm{i}}$; when depicting desolate and melancholy feeling of a person in an exotic foreign land, he describes as follows: "The moon, tiring, swims toward the horizon"(p.68); and as to the heart-wrenching understanding between a pair of lovers, he writes: "And then it hits me, the way a hoe hits a snake over the skull'(p.52). In The Letter, when talking about the protagonist and her younger sister's imagination about the big Ferris wheel and the dreamy Thames river, he describes like this: "The Thames smells like water-melon"(p.87). And at the beginning of the fiction, the protagonist's old grandmother "turning one page and licking her fingers to turn the next, like the ink on her fingers is honey" (p.77).

\section{Culture}

As we can see from the short story, the writer inserted some historical episodes into it — in order to fully grasp the meaning of those descriptions, we should first get to know the real history of the country and the nation. Bulgaria is a fascinating country in Balkans with a long history and rich and colorful civilization. The most ancient ethnic groups in this land are Macedonians and Thracians; at the beginning of the Middle Ages, a combination of Southern slaves and 
Turkic Bulgars came to settle on this land and they began to fight for their fate to get rid of the oppression of Great Powers in south and east Europe. Bulgarian is one of the South Slavic languages and written in Cyrillic alphabet. The period from 1944 to 1953 was the communist era. And the communist party has played a significant role in the historical changes of Bulgaria government. The communist party of Bulgaria led its people to fight against the Fascism and built the first people's democratic regime. However, due to the complicated combination of many different ethnics of the country, there were numerous splitting opinions about the party and its behaviors. Lots of folk tales and legends were thus spread and handed down. In the short story, he told tales and stories of his grandfather and grandmother, which added the exotic features of his writing.

\section{Cultural Equivalence and Acceptability Principles}

For literary translation, the key point of the translator should be how to reproduce the vivid image (character, situation and event) of the original work in order to achieve the goal of preserving the original work's artistic charm. This requires the translator to translate with a mission to positively introduce the primitive culture and try to convey the cultural characteristics and artistic beauty of the original work. In the end, the translator could faithfully reproduce the overall cultural atmosphere of the original work as much as possible. Therefore, only by following the requirements and principles above can translated work possess their unique literary value. In that way, we can achieve this purpose from two aspects: firstly, maintaining the original image; secondly, maintaining the exotic features of the image(杨晓荣， 2013 : 71). In the mean time, the translator not only maintains the original work's artistic charm, but also conveys the cultural information implied in those images.

However, cultural equivalence principle does not mean that we translators must rely on this principle all the time in the whole translation process. It just demands us to reproduce the overall cultural atmosphere of the original work, to avoid breaking the consistency of the cultural context. At the same time, we should keep the "thickness" of the atmosphere in an appropriate level. To avoid the situation of translators drawing too much attention on the cultural equivalence to the extent of going from extreme to the ridiculous, we also need to follow a principle that complementary to the cultural equivalence principle, that is, acceptability principle.

Acceptability principle requests translators to take the target language readers' psychological enduring capacity as the boundary when representing the cultural features of the original work. There is no doubt that the finished translation products of fictions should be those literary fictions that can fulfill general readers' appreciation of taste and have the same artistic appeal and literary beauty with the original work (if possible), rather than the text information for scholars and experts to do researches, without any missing details. In this case, we have to regard the acceptability of translation as an important factor to take into consideration.

During the translation process, if the referential meaning and the connotative meaning(or associative meaning) of the original text meaning came into conflicts, that is to say, while a target reader can enjoy the translated fiction, he cannot understand the original connotative meaning and the referential meaning at the same time. Or even worse, this may arise associations that are contrary to the original meaning, which would lead to the phenomenon of cultural incompatibility and bring about misunderstanding, inexplicability and even disgust. Hence, the translator should do some adjustments and changes about the images and vocabularies that cause wrong associations, in order to achieve the equivalence in a deep sense. Generally speaking, the limits of cultural equivalence should be consistent with the standard, within which there are no misunderstanding, inexplicability and disgust when the target readers are reading the translation. In addition, it's inadvisable for translators to put words into the target readers' mouth so that it underestimates the reader's receiving capacity.

Under different translation situations, the equinoctial point between maintaining exotic cultural features of the original works and giving consideration to the target readers' acceptance capability is just the "scale" of the cultural equivalence. If at particular level, the target readers have no difficulties in accepting and appreciating, but the translator does not convey and express this feature faithfully, and this phenomenon is called culturally under-translated, or the lack of cultural translation; On the contrary, if the literal translation of translated work caused cultural inexplicability, misunderstanding or disgust, or gave rise to the semantic overloading and meaning retardation, this situation will lead the translation to another extreme direction, namely, the culturally over-translated, or excessive cultural translation.

With respect to acceptability principle, for the translator, on the one hand, it should not replace the cultural equivalence principle, that is to say, the translator should restore the original cultural atmosphere in fiction translation; On the other hand, this principle may leave the boundary between acceptable and unacceptable blurred. As a consequence, translators' goal is supposed to seek a balance situation between cultural equivalence principle and acceptability principle, namely, a kind of "moderation", in order to obtain the optimum efficiency of cultural exchange and literary mood and its appreciation.

\section{Application and Analysis}

Example One: split down the middle, sixty-forty

Source language: She tells me to tie the end of a loose vine string, and while I tie it Grandmoms says,"I'm not saying, you know. But we could split down the middle."

I throw her this look. She says ,"Sixty-forty?"(p.77) 


\section{My version:}

她叫我把一根松垂的葡萄藤系紧，又对我说：“你知道的，我并不是在唆使你, 但是我们可以对半分。” 我瞟了她一眼。她又试探道: “要不四六分成?"

This is a simple conversation the protagonist--Mary and her grandmother, the key point to understand this sentence is the phrase "split down the middle" and "Sixty-forty". After looking up the dictionary, the author finds that "split down" means “combination of shares(并股)", “split down the middle" has the meaning of “从中间切开”. The author cannot figure out its exact meaning by seeing this paragraph alone. So the author continues to read, and from the rest of this story, the author notices that the protagonist does the servant work in Missis's house and she takes advantage of her work to steal jewelry, clothes and shoes occasionally, and then she will sell them for money. In this way, she and her grandmother make ends meet, and also can send money to her mother at set intervals. Combining with context, the author employs the method of liberal translation and translates "split down the middle" into"对半分", then "sixty-forty" can be translated into"四六分成". Then in the last sentence, the author adds two Chinese characters “要不” to bring out grandmother's tone of temptation and its implicit message. Moreover, it is much readable and comprehensible for the sake of being in accordance with idiomatical expressions of Chinese. In this case, the author on the one hand, is considerate of the acceptability of translated work in target language; on the other hand, it's conductive to correspond the character images of the protagonist and her grandmother with their utterance to show the status of the characters and to aptly convey their different emotions and personality traits.

\section{Example Two: give two shits}

Source language: I don't really give two shits about the Soviets falling, but Grandmoms makes me learn these things because she says I ought know my history.(p.79)

My version: 我真的他妈的一点儿都不在乎什么苏联解体，但是外婆非让我知道这些事情，她说我应当清楚 自己的身世。

This expression---"give two shits" seems a bit of strange and makes people confused. Therefore, this kind of translation can not fulfill the role of communicative function in the original text, and its emotional function is more obvious and important than its informative function. The author's version "真的一点儿都不在乎", employing liberal translation and omitting the deeper emotional information of "shits", which can only result in delivering the surface meaning of the sentence. The unique emotional function here is undoubtedly lost. The author takes the protagonist's inner struggle into consideration and adds a common pet phrase"他妈的" in the first sentence. In this way, the translated version not only properly presents the protagonist's inner struggle, mental activity, but also conforms to the speaking style and personality characteristics of a girl with little education.

\section{Example Three: Russian dog}

Source language: She is a Russian dog, salivating at the sight of me. She knows I always bring baskets.(p.78) My version: 太太很迷恋俄式的东西，所以每次一见到我就隐得流口水。她知道我篮子里总有好东西。

Reading this sentence at the beginning, the author could not understand the specific meaning of "Russian dog". After deep and careful discussions with my supervisor and teammates, and combines with context, the author finally get the idea that it means every time the protagonist comes to Missis's home, Missis is "salivating" over the stuff she brings, from which we can deduce that Missis must be very happy and yearn for the things. In Chinese culture, if we use dog to describe a person, it means that this man might be very envious and infatuated with some particular things. But it is not good to translate its superficial meaning word-for-word, according to the acceptability principle, the author decides to convey the figurative meaning of this sentence and translates it as “太太很迷恋俄式的东西”. As to the second sentence, I choose to deliver meaning of the sentence via a Chinese phrase “隐得流口水”, which is more aligned with the iconic nature of "dog" and also retains unique cultural information. Thus, target readers will be able to better understand the personal character of Missis. Another place that should be noticed is in the last sentence, the key point of "bring baskets" is actually falls on the stuffs in baskets. So I prefer the version “她知道我篮子里总有好东西”, which gives prominence to the key points “好东西”, and also achieves the equivalence of sentence pattern and meaning.

\section{Example Four: stomach}

Source language: I can't stomach this. (p 115)

My version: 我会受不了的。

In this sentence, the word "stomach" is not the part of our body but used as a verb. For example, if you can't stomach something, you can't accept it because you dislike it or disapprove of it. When using as a verb, it usually followed by "not". So the literal translation of this sentence is : 我无法接受。 
However, in literature translation, words and sentences are not always taken as what they mean literally and sometimes, for the sake of recreation, the translator has to do some creative changes during the converting process. "We can't say no," she said. "We have no right to say no. But I can't come with you. I can't stomach this." According the context and the situation, this sentence uttered by Yuki reflected her fear and regret after the accident. So the author thinks that "我 会受不了的” is better.

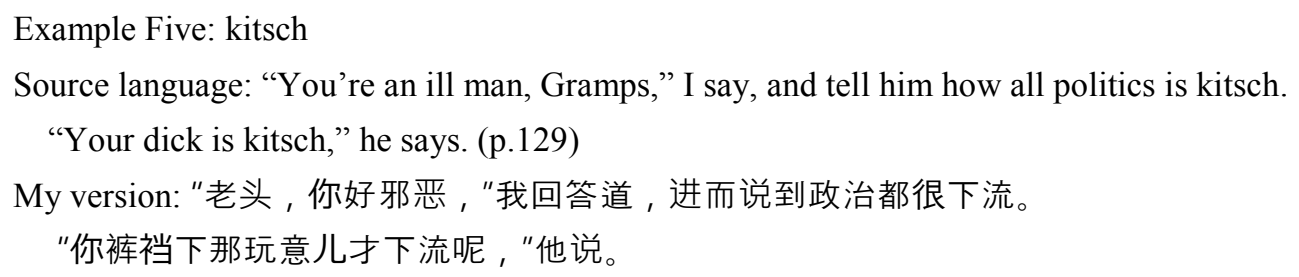

Here is the dialogue between Rado and the guard of school. The guard is a veteran and he is a special social signspeculator of that period. He makes a profit in the unrest and incites Rado to steal school public properties, and then makes story for them in order to seek exorbitant profits. The guard is hostile to the society and the government but he is a thoughtful and clear-sighted man. His words maybe coarse but not dirty. When translating "dick", the author uses words to show the guard's language style. “阉掉” and “裤裆下那玩意儿” is appropriate. However, the word “kitsch” is another difficulty while translation. At first, the author translate it into “粗俗之物”, and then the supervisor change it into “下流的”, the latter is more adapted to the language style. For a teenage, especially a desultory teenage, “粗俗之物 " is too cliché.

Example Six: draw a star

Source language: "Chill there, Gramps," I say. "Can’t you see I'm drawing a star?” (p.127)

My version: "老头，走开，"我说。“你看不到我在画地图吗?"

“Draw a star" is an English slang or folk adage. Here it refers to urinate in public. If translated into “画星星”, it would be confusing to Chinese readers. But this phrase can be equivalently substituted to “画地图”, which shares the meaning in Chinese, especially in childhood. The key to translation is making clear of the original version, so this equivalent substitution is perfect not only in communicating to the author's idea but also in adapting to the language style - the use of slang.

\section{Example Severn: wrecked}

Source Language: They thrashed, wrecked, shattered and then curled up in the corner, curs who'd recognized their master.(p.91)

My version: 音符肆意的摇摆，猛烈地撞击，哗啦啦碎了一地，蚣缩在角落里，像自家的狗见了主人。

Penkov described force of the music played by Kemal and her father with the help of three verbs-thrash, wreck and shatter. Thrash means "move in a wild or violent way, often hitting against something", so the author adds three characters “肆意的”; Wreck means “to completely ruin or destroy something”, thus the author translates it into “猛烈的 撞击"; Shatter means "to break into a lot of small pieces". Considering images evoked by the word "shatter" in readers of original, onomatopoeia “哗啦啦” was added in target language to maintain the balance between information conveyed by the original and the target text.

\section{Example Eight: KULAK}

Source Language: My great-grandfather asked to be excused on a moment and returned with his shotgun. How things unfolded exactly I don't know in detail, but he ended up shooting one of the boys dead. Three days later the comrades returned, summoned an improvised people's court, declared my great-grandfather an enemy of the people and hanged him on the lower branch of the walnut tree. They made Grandpa, then in his twenties, watch and draw conclusions about his own future. The comrades wrote KULAK on the gates in big tarry letters so everyone who passed by would know our family was a class enemy. (p. 108)

My version: 祖父借口离开了一会，等他再回来时，手里多了一杆枪。具体细节是怎样的我不太清楚。但是 结果就是他射杀了其中一个。三天后，其他的同志返回此地，召开了一个临时法庭，宣布曾祖父为人民公 敌，将他吊死在矮矮的胡桃树的枝桠上。他们让我爷爷，当时他二十来岁，亲眼目睹这一幕，并让他自己 选择命运前途。那些同志用柏油在我们家的大门上写下了大大的字母—KULAK ( 地主 ) 一一好让过路 人都知道我们是阶级敌人。 
When translating this paragraph, the author felt confused and pinned until learning the background of this period of history. Words like "集体农庄"、“人民公敌"“地主”and "阶级敌人"look familiar to readers, because we Chinese people also experienced the same times and those class political words already exist and couldn't be easily forgotten. The word "KULAK" is the emphasized form of "Kulak" which means "rich farmers" in Russia. We can get the Chinese counterpart “富农”in dictionary and so did the author translated it as “地主”. By using the parallel language and words, the author found an easy way for readers to better understand the text, and it also reflected the translator's subjectivity.

\section{Conclusion}

During this translation practice, the first principle that the author follows is cultural equivalence principle, which requires the author to be faithful to the entire cultural atmosphere of the original text in fiction translation. This principle is the foundation for the realization of the original culture value and artistic value. In order to remodel the original cultural atmosphere to the greatest extent, the author tries his best to retain the cultural information of original text for the reproduction of their cultural features. In this process, we can also bring in new forms and statements to provide fodder for its own development of target language. In the meantime, the equivalence between the translation version and the original text will be limited by many factors during the translation process. In terms of cultural characteristics, target readers' acceptance level plays a significant role while determining the degree of cultural equivalence under specific circumstances. So here comes the second principle to follow: the acceptability principle. In addition to these two principles, "in translation practice, being aware of those obviously unaccepted details and expressions can help to avoid over-domestication, and being aware of target readers' dynamic and highly motivated expectations while appreciating translated stories will do good to get rid of over-foreignization” (杨晓荣, 2013: 164). We translators also have the responsibility of gradually helping target readers open their views on the "fusion of horizons" through our tireless efforts. Therefore, the task of seeking the balance point between maintaining the cultural features of original text and making the translation version more acceptable and popular by target readers in language and culture level is not only essential, but also possible to fulfill in most cases.

\section{References}

Penkov , M. (2011). East of the West: A Country in Stories. New York: Farrar, Straus and Giroux.

杨靖. (2013). 米洛斯拉夫.潘科夫：只有通过写作，他㨢走进故乡，《文艺报》, 2-22.

Jing, Y. (2013).Introduction of Miroslav Penkov's Writing. Journal of Liberal Arts.

杨晓荣. (2013). 小说翻译中的异域文化特色问题, 广州：世界图书出版广东有限公司

Xiaorong, Y. (2013). The Features of Exotic Culture in Literary Translation. Guangzhou: World Books Publishing CO. LTD. in Guangdong.

Notes

${ }^{\mathrm{i}}$ Miroslav Penkov, East of the West: A Country in Stories, Farrar, Straus and Giroux, 2011. For the following quotations, only the pages are indicated in brackets. All the Chinese versions are selected from my postgraduate students' translational project reports (宋丹丹、郑毅、苏文倩、梁昕诺) in 2014. 